\title{
THE ROSE GARDEN OF THE WORLD: Near East Imagery in the Poetry of Walt Whitman
}

\author{
ARTHUR L. FORD
}

THERE HAVE BEEN FEW SIGNIFICANT STUDIES of the influence of the Orient, whether the Near or Far East, on American poetry during the nineteenth century. Arthur Christy's 1932 work, The Orient in American Transcendentalism, ${ }^{1}$ surveys the Transcendentalist's indebtedness to the poetry, religion, and philosophy of the Orient, but his examination of the Near East, what we now call the Middle East, ${ }^{2}$ was limited to little except Persian poetry. He dismissed Mohammedanism, except for the Sufi sect, as offering nothing not already available to American writers in the Old Testament. Christy's work is still valid scholarship, but by limiting his discussion of the Near East to Persian poetry and Sufism he ignored much that informed the popular and poetic imagination of America.

It is now clear that the Levant and its surroundings loomed large in the nineteenth-century American imagination. Edward Said's Orientalism ${ }^{3}$ discusses its effect on the European colonial mind during the nineteenth century and the American colonial mind during the twentieth. More recently, at Damascus University, Fuad Shaban has demonstrated that the idea of the Orient preoccupied nineteenth-century Americans, appearing in so many religious tracts, political papers, travel accounts, poetry, and fiction that it created a series of stereotypes. I propose that images of the Near East play a more prominent role in American poetry of the last century than most scholars have recognized, particularly in the work of Walt Whitman, that most American of poets; thus it is worthwhile to consider how he uses those images.

Since Whitman read extensively, it was inevitable that the ubiquitous imagery of the Orient would find its way into his poetry. ${ }^{4}$ But careful examination suggests his interest centered on two specific areas of Near East studies: the Persian poets, such as Hafiz and Saadi, who were associated with a mystical offshoot of Mohammedanism known as Sufism, and Egyptology. Whitman's interest in Persian poetry begins in the early years of Leaves of Grass. He owned a copy of W. R. Alger's The Poetry of the East, ${ }^{5}$ published in 1856 , and according to his words on the fly-leaf he often read the lengthy Introduction to this collection of poetry by Arabs, Hindus, Persians, and Sufis "over and over." He carried it with him during part of the Civil War, reading it "sometimes to hospital groups, to while away the time." 6 Undoubtedly he also read Emerson's article, "Persian Poetry," in the Atlantic Monthly in 1858. Emerson introduced his readers to Persian poetry in this essay, par- 
ticularly "the seven masters of the Persian Parnassus": Firdusi, Enweri, Nisami, Jelaleddin, Saadi, Hafiz, and Jami. ${ }^{7}$

Similarly, Whitman developed a consuming interest in Egyptology. The West had been curious about Egypt ever since Napoleon's campaigns there, and interest became fascination when Champollion published the result of his explorations in the Précis du Système Hieroglyphique des Anciens Egyptiens in 1824. Whitman was also familiar with books such as C. K. J. Bunsen's Egypt's Place in Universal History, J. G. Wilkinson's Manners and Customs of the Ancient Egyptians and George Glidden's Ancient Egypt. ${ }^{8}$ The seriousness of Whitman's study is evident from his visits to Dr. Henry Abbott's personal collection of Egyptian antiquities at his museum in New York City. Whitman speaks of "long talks with him, in connection with my readings of many books and reports on Egypt -its antiquities, history, and how things and the scenes really look, and what the old relics stand for, as near as we can get to them." $\mathrm{He}$ even wrote an article in 1855 on the museum for Life Illustrated, a phrenologist magazine. Gay Wilson Allen noted that "this article reveals not only an intimate knowledge of the collection but also a surprising familiarity with the literature of the collection," adding that "the echoes, allusions, and references to Egyptology in Leaves of Grass are so numerous that one must conclude that Whitman read the works closely and took notes on them." 10 Whitman finished his article with a plea for the more learned people of New York to support Abbott's museum, insisting that "A man must study it in connection with his reading of ancient history-in connection with long and deep trains of thought."11 Worth noting, however, is that Whitman shared with his age the popular stereotype of the modern Egyptian, for he described the people of modern Egypt as "degraded and unmanly, . . . the offices and officers are one reeking mass of selfishness and rapacity, and bribery and rottenness, without any exception whatever."12

Not surprisingly, Whitman's friends and contemporaries spotted the presence of the Near East, particularly Persian poetry, in his work. Edward Carpenter referred to Whitman's roots as being found in, among other sources, "the mystics of Egypt, the Sufis of Persia."13 Lord Strangford, an important British student of the Orient, felt that Whitman's technique was filled "with not only the spirit, but with the veriest mannerism, and most absolute trick and accent of Persian poetry."14 Even Thoreau, though often confounded by Whitman's poetry, noted that the first edition of Leaves of Grass sounded "wonderfully like the Orientals."15

As might be expected, much of Whitman's Near East imagery appears as items in the catalogues he uses to suggest breadth, diversity, or representativeness. The poem with the largest number of Near East images, more than twice any other, is "Salut au Monde!", first published in the 1856 Leaves of Grass. But the poem dealing most directly with the Near East, "A Persian Lesson," did not appear until the 1891 Good-Bye My Fancy and was added later to the final edition of Leaves of Grass. Both employ Whitman's cata- 
logue technique, and both reveal his understanding of the contribution Near East imagery made to his poetry.

"Salut au Monde!" is structured as an address to Whitman himself and moves quickly to lists of images throughout the world. "What widens within you Walt Whitman?" he asks. "Within me latitude widens, longitude lengthens" (1. 14), ${ }^{16}$ he responds, and specifies the range and variety of the world within himself. In the course of that listing, primarily of hearing and sight in direct address ("You ...."), Whitman scatters thirty-four clearly identifiable Near East images throughout the poem. In section three, for instance, responding to the question "What do you hear Walt Whitman?" (1.22), he uses four lines to represent the Near East. After a line referring to the sound of locusts striking the grain in Syria, he suggests inclusiveness by noting the holy sounds of the three main religions of the area: the Christian: "I hear the coptic refrain toward sundown, pensively falling on the breast of the black venerable vast mother of the Nile" (1. 31); the Moslem: "I hear the Arab muezzin calling from the top of the mosque" (1. 33); and the Jewish: "I hear the Hebrew reading his records and psalms" (1.37). More important, however, is his non-judgmental representation of these sounds, remarkable because most Americans, including Whitman at times, saw the Near East as inferior to everything in the West.

Sections four through ten, approximately 120 lines, answer the question, "What do you see Walt Whitman?" (1.40) Here again the answer is expansive and includes six lines of Near East imagery. Several merely list: "I see Lybian, Arabian, and Asiatic deserts" (1. 55); "I see the site of the old empire of Assyria, and that of Persia, and that of India (1. 91); "I see Teheran, I see Muscat and Medina and the intervening sands, I see the caravans toiling onward" (1. 146). But two lines reflect Whitman's deep interest in Egyptology. The first image could be found in the minds of all Americans at the time: "I see Egypt and the Egyptians, I see the pyramids and obelisks" (1. 147). The other image, however, was less recognizable but nonetheless accurate: "I see at Memphis mummy-pits containing mummies embalm'd, swathed in linen cloth, lying there many centuries" (1. 149). Finally, in this section of sight, Whitman includes another stock figure of the Near East held by the West: "I see the Turk smoking opium in Aleppo" (1. 144). But this image, however clichéd, reflects again the accuracy of Whitman's knowledge, for he placed the Turk in Aleppo since he knew the Ottoman Empire extended south into Syria.

The last section of "Salut au Monde!" directly addresses the world and thus representativeness is important. Whitman listed Armenians by the Euphrates (1. 184), pilgrims on their way to Mecca (1. 185), sheiks ruling their tribes (1. 186), and olive growers in Nazareth, Damascus, and Lake Tiberius (1. 187). But he also included more specific images, such as the Jew who returns to the Holy Land, "You Jew journeying in your old age through every risk to stand once on Syrian ground" (1. 182), and to the Jews elsewhere in the 
world, "You other Jews waiting in all lands for your Meśsiah!" (1. 183). These two lines echo the nineteenth-century American idea of the Near East as the land God promised to the Jews. In fact, as M. A. Shaban points out, the concept of a Jewish homeland was intimately tied with the Puritan concept of a promised land in early New England. Whitman's images reflect this longstanding view of the Near East but with understanding and insight. His reference to "Syrian ground" shows an uncommon knowledge of the region's history. But apart from these references to the Jewish homeland, Whitman reverts to conventional images, contrasting the romantic daring of the Persian horsemen - "You beautiful-bodied Persian at full speed in the saddle shooting arrows to the mark!" (1. 179) - with the dirty desert nomad-"You haggard, uncouth, untutor'd Bedowee" (1. 206).

In more than a dozen other poems, Whitman incorporated images of the Near East, most functioning as they do in "Salut au Monde!"-as contributors to the inclusiveness of his vision. In "Old Chants," he refers to Persian epics (1. 10), and when he lists the various chants he includes those of Egyptian priests (1. 9). Similarly, among his catalogues in "Proud Music of the Storm," he includes the "sound of the Hebrew lyre" (1. 103), "the Egyptian harp of many strings" (1. 116), "the primitive chants of the Nile boatmen" (1. 117), and the calling of the muezzin from the "Musselman mosque" (1. 113), all traditional, even stereotypical images in the nineteenth-century American imagination, as is this, the most common of all:

\section{I hear dervishes monotonously chanting, interspers'd with frantic shouts, as they spin around turning always to Mecca. (1. 105)}

Whitman uses Near East images in predictable ways in other poems as well. As might be expected in "Passage to India," a poem circling the world, Whitman includes a sampling of Near East images, several describing the recently opened Suez Canal. Others expand the range of the poem. One line lists an indiscriminate number of people: "The traders, rulers, explorers, Moslems, Venetians, Byzantium, the Arabs, Portuguese" (1. 138). Another line juxtaposes distant lands: "On one side China and on the other side Persia and Arabia" (1. 132). But he also reaches back into the distant past of civilization by referring to the Euphrates River: "The river Euphrates flowing, the past lit up again" (1. 126).

In "Song of the Exposition," Whitman again describes the Near East to suggest the inclusiveness of his vision. Egypt appears in several lines: "Silent the broken-lipp'd Sphynx in Egypt, silent all those century-baffling tombs" (1. 39); "Mightier than Egypt's tombs" (1. 73); "Your Alexandrian Pharos, gardens of Babylon" (1. 112). Jerusalem, especially the devastated, lost Jerusalem of antiquity, he describes as "Jerusalem a handful of ashes, blown by the wind, extinct" (1. 43).

Surprisingly, "Song of Myself," despite its length, contains relatively 
few references to the Near East. One line merely lists several Middle Eastern gods with others from the Far East: "Buying drafts of Osiris, Isis, Belus, Brahma, Buddha" (1. 1030). The appearance of Osiris and Isis is to be expected because of of his knowledge of Egypt; however, Belus, or Bel, was not ordinarily known. Perhaps Whitman had in mind the more general term Baal, used in Biblical times to refer to a variety of local sun gods, but he does use the more precise term here. Although most of the Near East images in "Song of Myself" merely contribute to range and diversity, several are specific to Egyptian hieroglyphics, that mystery that had recently been solved in Champollion's book. Whitman refers to the grass itself as a hieroglyphic, revealing secrets known to nature (1. 106). Later in the poem he exalts those who unlock secrets, including those who "made a grammar of the old cartouches" (1. 487). ${ }^{17}$ The final image of the Near East appears in section thirtytwo, where Whitman says he is "afoot with my vision." Among the many companions who accompany him on his stroll he includes Jesus: "Walking the old hills of Judaea with the beautiful gentle God by my side" (1. 790).

These images from the Near East are as casual and unexceptional as Whitman's images from most sections of the world. The poet of inclusiveness, after all, could not ignore any important part of the whole, especially a part so much in the consciousness of his time. In "A Persian Lesson," however, Whitman moved past mere accretion of Near East images to a more profound portrait of culture. This poem directly uses not only the images but also the philosophy of Persia, now modern Iran. The "lesson" is taught by a Sufi, one of the holy men of Sufism, a mystical branch of Islam that has as its goal union with God and that relies on intuition as the path to truth. Alger, in the book Whitman knew so well, identified the Sufis this way:

The Sufis are a sect of meditative devotees, whose absorption in spiritual contemplations and hallowed raptures is unparalleled, whose piety penetrates to a depth where the mind gropingly staggers among the bottomless roots of being, in mazes of wonder and delight, and reaches to a height where the soul loses itself among the roofless immensities of glory in a bedazzled and boundless ecstasy. ${ }^{18}$

Massud Farzan has called this poem a "surprisingly accurate and inspired reflection of Persian Sufism." He continues, "It is altogether conceivable that Whitman had been influenced more by Persian Sufi poetry than by any other mystical works and that his unique old-age poem 'A Persian Lesson' presents a marvelous fruition of a long acquaintance with and immersion in Sufism." Indeed, the poem was originally entitled "A Sufi Lesson." While Farzan does not discover Persian or Sufi images in Whitman's other poetry, he does draw parallels between Whitman and Jalah al-din Rumi (1207-1273), a Sufiinspired Persian poet, regarding their concrete representation of the mystical, especially through physical and erotic love poetry. Farzan suggests that "'A Persian Lesson' contains the essence and synthesis of his earlier poems ... a fitting coda for Leaves of Grass because of its serenity and its mystical sense 
of wholeness."19 Another critic, Ghulam M. Fayez, claims that Whitman is closest to Rumi "by affinity of mystic temper as well as poetic characteristics," and he suggests that Rumi may have been Whitman's inspiration for "A Persian Lesson."20

The poem contains two parts. In the first five lines Whitman introduces the Sufi who is about to give his final lesson in the open air of a Persian rosegarden beneath an ancient chestnut tree:

\footnotetext{
For his o'erarching and last lesson the greybeard sufi, In the fresh scent of the morning in the open air, On the slope of a teeming Persian rose-garden, Under an ancient chestnut-tree wide spreading its branches, Spoke to the young priests and students.
}

The rose-garden is a common image in Persian or Suf poetry and thus a natural setting for Whitman to use. The chestnut tree, while found in the Near East, is less frequently found in poetry, but the image of an overarching lesson beneath the spreading branches of the tree underscores the encompassing unity of that experience. Whitman used these images to his own ends, but it is unlikely he was aware of the elaborate, even arcane, vocabulary of Sufi poetry. In that system, each image carries one or more specific meanings, forming a language that allowed the Sufi poet to speak of one thing entirely in terms of something else, a useful device for a sect often accused of heresy. For instance, the rose-garden is synonymous with the soul, a meaning entirely consistent with the poem and which Whitman may have known. One doubts, however, he knew that an arch, or an image comparable to it, represents on one level the prayer niche of the mosque, and therefore, on another level, the entrance to communication with God. Whitman also refers to the scent of the morning. In Sufi poetry aromas represent the unseen conveyance of God's message to man and of man's message to God. Although the American Transcendentalists used metaphors of scent in the same way, since images of perfume often function this way for poets regardless of cultural heritage, for the Sufi poet the scent of a rose has a special significance. According to legend, the rose grew from a drop of the Prophet's perspiration as he ascended into heaven. Whitman could not have had this legend in mind; rather he was reacting to his reading of Persian poetry, and his choice of images was clearly affected by that reading.

Despite Whitman's unorthodox use of Persian antecedents, his choice of theme closely and deliberately parallels Sufi philosophy. The lesson reveals Whitman's understanding of Sufism, even incorporating portions of the muezzin's call to prayer, heard five times a day in the Moslem world: "Allah is all, all, all" (1. 7). As Christy and F. O. Matthiessen have pointed out, Sufism appealed to Whitman as well as to other American Romantics because the philosophy mirrored their own. In other words, the Sufi's lesson is pure Sufism, but also pure Whitman, particularly when the Sufi tells his disciples 
that Allah is everywhere and in all things, in "each word, each part of the rest" (1. 6). Fayez says of the similarity between Whitman and Rumi, "Since the transcendent self, as experienced by Rumi and Whitman, is dynamic, fluid, microcosmic and macrocosmic, it can occupy infinite centers and overlap infinite centers at one time. It may transmit itself into one thing and become that thing for a while, as it does in 'Song of Myself,' but its essential aim is to achieve unity-in-diversity by encompassing life wholly and lovingly."22 The nature of the Sufism in "The Persian Lesson" can be understood further by looking at the Introduction to The Poetry of the East, that section Whitman read repeatedly. There Alger says that Sufism aims for "a union with God so intimate that it becomes identity, wherein thought is an involuntary intuitive grasp and function of universal truth." ${ }^{23}$ Among the principal characteristics of Oriental poetry, Alger includes an "ardent pantheism." ${ }^{4}$ Clearly, "A Persian Lesson" fulfills both the Sufic concept of pantheism-as understood by the nineteenth century-and Whitman's own.

The "greybeard Suf" poses a series of quesions, asking his disciples if they would like to know the answer to the fundamental questions of existence: "Would you know ... the invisible need of every seed?" (11. 11-12). He then gives the answer, one that he, as well as Emerson and Thoreau, both familiar with Sufism, had given many times before:

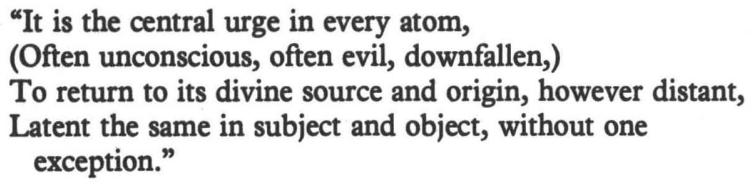

The return to the divine source is Emerson's return to the Oversoul or Whitman's return to the Great Float or the Mother of the Sea.

This brief survey illustrates how Whitman used the imagery of the Near East to suggest the range and diversity of his own experiences and thus the experiences of the race. That he used few, and sometimes predictable, symbols is understandable, given his time and place and his passion to be that most American of poets. What is remarkable, and worthy of further study, is how his early and continuing fascination with the ideas and images of the Near East shaped his philosophy as well as his poetry.

\section{Lebanon Valley College}

\section{NOTES}

1 Arthur E. Christy, The Orient in American Transcendentalism (New York: Columbia University Press, 1932). 
2 I am using the term Near East to include Israel, Lebanon, Syria, Egypt, Jordan, Saudi Arabia, Turkey, Iraq, and Iran. In the nineteenth century all were predominantly Moslem, and except for Turkey and Iran, predominantly Arab.

3 Edward Said, Orientalism (New York: Vintage Books, 1978).

4 There are two useful sources tracing Whitman's reading: Floyd Stovall, "Notes on Whitman's Reading," American Literature, 26 (November, 1954), 337-362; and, Notes and Fragments: Left by Walt Whitman, ed. R. M. Bucke (Ontario: A. Talbot \& Co., 1899), particularly Part VI, 193-211.

5 William Rounseville Alger, The Poetry of the East (Boston: Wittemore, Niles, and Hall, 1856).

6 Roger Asselineau, The Evolution of Walt Whitman: The Creation of a Book (Cambridge: Belknap Press, 1962), 302.

7 Ralph Waldo Emerson, "Persian Poetry," The Complete Writings of Ralph Waldo Emerson (New York: Wm. H. Wise \& Co., 1929), 799.

8 Robert D. Richardson, Jr., Myth and Literature in the American Renaissance (Bloomington: Indiana University Press, 1978), 149. See also the Stovall article cited above, 338-339.

9 Gay Wilson Allen, The Solitary Singer: A Critical Biography of Walt Whitman (New York: New York University Press, 1955), 121.

10 Allen, 121-122.

11 Walt Whitman, "One of the Lessons Bordering Broadway-The Egyptian Museum," New York Dissected: ASheaf of Recently Discovered Newspaper Articles by the Author of Leaves of Grass, ed. Emory Holloway and Ralph Adimari (New York: Rufus Rockwell Wilson, 1936), 40.

12 New York Dissected, 35.

13 Edward Carpenter, Days with Walt Whitman (New York: Macmillan Co., 1906), 29.

14 Gay Wilson Allen, A Reader's Guide to Walt Whitman (New York: Octagon Books, 1971), 28. Allen quotes from "Walt Whitman," The Pall Mall Gazette, 16 February 1866, reprinted in A Selection from the Writings of Viscount Strangford (London, 1869), 2:297.

15 Thoreau further asked Whitman if he had ever read the Orientals. According to Thoreau, Whitman responded, "No, tell me about them." Thoreau, a student of the Far East, perhaps had that source in mind rather than Egypt or Persia. See F. B. Sanborn, ed., The Writings of Henry David Thoreau, vol. 6 (Familiar Letters), 295-296.

16 Sculley Bradley, Harold W. Blodgett, Arthur Golden, and William White, eds., Leaves of Grass: A Textual Variorum of the Printed Poems (New York: New York University Press, 1980), 1:162. All line numbers are from this edition.

17 Holloway and Adimari point out in a note to Whitman's article on Abbott's Museum that this line "probably" refers to Champollion.

18 Alger, 64.

19 Massud Farzan, "Whitman and Sufism: Towards 'A Persian Lesson," American Literature, 47 (January, 1976), 573-582.

20 Ghulam M. Fayez, "Motion Imagery in Rumi and Whitman," Walt Whitman Review, 25 (June, 1979), 39.

21 For a concise account of the current view of Sufi poetry, see Annemarie Schimmel, As Through a Veil: Mystical Poetry in Islam (New York: Columbia University Press, 1982). 
22 Fayez, 51.

23 Alger, 65.

24 Alger, 78. 